Article

\title{
Dynamic In Vivo Profiling of DNA Damage and Repair after Radiotherapy Using Canine Patients as a Model
}

\author{
Nadine Schulz ${ }^{1}$, Hassan Chaachouay ${ }^{1}$, Katarzyna J. Nytko ${ }^{1,2}$, Mathias S. Weyland ${ }^{3}$, \\ Malgorzata Roos ${ }^{4}$, Rudolf M. Füchslin ${ }^{3}$, Franco Guscetti ${ }^{5}$, Stephan Scheidegger ${ }^{3}$ \\ and Carla Rohrer Bley ${ }^{1,2, *}$
}

1 Division of Radiation Oncology, Vetsuisse Faculty University of Zurich, CH-8057 Zurich, Switzerland; nschulz@vetclinics.uzh.ch (N.S.); Hassan.chaachouay@gmail.com (H.C.); knytko@vetclinics.uzh.ch (K.J.N.)

2 Center for Applied Biotechnology and Molecular Medicine (CABMM), University of Zurich, CH-8057 Zurich, Switzerland

3 ZHAW School of Engineering, Zurich University of Applied Sciences, CH-8400 Winterthur, Switzerland; weyl@zhaw.ch (M.S.W.); furu@zhaw.ch (R.M.F.); scst@zhaw.ch (S.S.)

4 Department of Biostatistics, Epidemiology Biostatistics and Prevention Institute, Faculty of Medicine, University of Zurich, CH-8001 Zurich, Switzerland; malgorzata.roos@uzh.ch

5 Institute of Veterinary Pathology, Vetsuisse Faculty University of Zurich, CH-8057 Zurich, Switzerland; franco.guscetti@vetpath.uzh.ch

* Correspondence: crohrer@vetclinics.uzh.ch

Academic Editor: Guillermo T. Sáez

Received: 5 April 2017; Accepted: 27 May 2017; Published: 1 June 2017

\begin{abstract}
Time resolved data of DNA damage and repair after radiotherapy elucidates the relation between damage, repair, and cell survival. While well characterized in vitro, little is known about the time-course of DNA damage response in tumors sampled from individual patients. Kinetics of DNA damage after radiotherapy was assessed in eight dogs using repeated in vivo samples of tumor and co-irradiated normal tissue analyzed with comet assay and phosphorylated H2AX $(\gamma \mathrm{H} 2 \mathrm{AX})$ immunohistochemistry. In vivo results were then compared (in silico) with a dynamic mathematical model for DNA damage formation and repair. Maximum \%DNA in tail was observed at 15-60 min after irradiation, with a rapid decrease. Time-courses of $\gamma \mathrm{H} 2 \mathrm{AX}$-foci paralleled these findings with a small time delay and were not influenced by covariates. The evolutionary parameter search based on \%DNA in tail revealed a good fit of the DNA repair model to in vivo data for pooled sarcoma time-courses, but fits for individual sarcoma time-courses suffer from the heterogeneous nature of the in vivo data. It was possible to follow dynamics of comet tail intensity and $\gamma \mathrm{H} 2 \mathrm{AX}$-foci during a course of radiation using a minimally invasive approach. DNA repair can be quantitatively investigated as time-courses of individual patients by integrating this resulting data into a dynamic mathematical model.
\end{abstract}

Keywords: DNA damage repair; kinetics; $\gamma \mathrm{H} 2 \mathrm{AX}-\mathrm{foci}$; comet assay; dog; radiation; DNA repair model

\section{Introduction}

Monitoring the formation of damage in a cell after radiotherapy (RT) and the evaluation of DNA repair markers may be a means to provide information on intrinsic radiosensitivity and radio-responsiveness [1-3]. Ionizing radiation used as a cancer treatment relies on the formation of direct DNA damage or on creating sufficient cellular damage leading to double strand breaks (DSBs), which in turn trigger the activation of cellular death pathways. Upon damage, the cells 
activate a DNA-damage response, consisting of various pathways which will sense the extent of damage and induce an effector pathway either leading to cell death, cell cycle arrest, or DNA damage repair [4]. DNA damage detection from patient samples has been performed for various tumor groups irradiated ex vivo, resulting in robust correlations with radio-responsiveness, as known from clinical behavior [2,5]. Furthermore, monitoring the responses towards damage formation and repair from individual tumors may offer a legitimate chance to monitor cancer treatment and even a possibility to predict clinical response to treatment [6,7]. This is thought to hold true even in spite of the high inter-tumoral and inter-patient heterogeneity that is to be expected from patient samples [6,7].

While the time-courses in responses to different DNA damaging agents have been well characterized in cultured tumor cells in vitro, little is known about the time-course of DNA damage response in tumor and normal tissues sampled from individual tumor patients [2,5,6,8-10]. Specifically, actual time-courses from patients undergoing radiation therapy are lacking. Time resolved data of DNA damage formation and repair can be used to elucidate the relation between DNA damage formation, repair, and cell survival. It can be expected that, for example, a higher amount of DNA fragments in the tail of a comet assay or residual phosphorylated H2AX foci $(\gamma \mathrm{H} 2 \mathrm{AX}$-foci) are an indication of higher initial radiosensitivity.

The aim of this study was twofold: first, we wanted to use the minimally invasive sampling techniques (fine needle aspirates (FNAs)) and small biopsies for repeated in vivo patient sampling and subsequent biostatistical quantification of the amounts and time-courses of DNA damage produced by therapeutic ionizing radiation. As a model, sampling was performed in canine tumor tissue as well as co-irradiated normal tissue from patients undergoing treatment. In order to study DNA damage in samples of low cellularity, the comet assay [11-13] was used to detect DNA breaks at the level of individual cells in a rapid, sensitive, and simple manner. To validate our data from the alkaline comet assay and to gain additional information, staining of $\gamma \mathrm{H} 2 \mathrm{AX}$-foci was performed in parallel at several time-points after treatment with RT [14]. Second, the clinical in vivo results were then compared (in silico) with a dynamic mathematical model for DNA damage formation and repair. With the postulation of a second order decay (removal) of DNA fragments in the comet tail, the goal of the introduction of clinical patient data into such a tumor-patient model is to identify characteristic kinetic constants and delay times [15].

By integrating the repeated, minimally invasive in vivo measurements of clinical patients treated with RT into a mathematical model based data analysis, the potential of a computer simulation of such time-courses was strengthened. This in turn will allow its future use in a more comprehensive framework for the interpretation of obtained patient data and for guidance of therapy.

\section{Results}

\subsection{Patient, Tumor, and Radiation Dose Characteristics}

Serial samples from eight patients were available. Of the eight dogs, four were female (two spayed) and four were neutered males. The dogs were of various pure $(n=5)$ and mixed breeds $(n=3)$ and a total of five breeds were represented. The ages ranged from 8.17 to 13.67 years with a mean of $11.28( \pm 1.63)$ years. The weights ranged from 11.00 to $38.50 \mathrm{~kg}$, with a mean of $23.73( \pm 8.51) \mathrm{kg}$. Tumor volumes ranged from 9.24 to $97.91 \mathrm{~cm}^{3}$ with a mean of $27.43 \mathrm{~cm}^{3}( \pm 29.33)$. Of the eight cases, six tumors $(75 \%)$ were histologically described as canine soft tissue sarcoma and two (25\%) as oral malignant melanoma. Radiation therapy was applied in $5 \times 6$ Gy over 2.5 weeks in seven patients and in $4 \times 8$ Gy in one patient (with malignant melanoma).

\subsection{Comet Assay: Tail Intensities (\%DNA in Tail) after Radiotherapy in Tumor Samples}

Compared to pre-treatment $\left(\mathrm{T}_{0}\right)$, the measured \%DNA tail peaked at 15 to $60 \mathrm{~min}$ after RT. The maximum \%DNA in tail was observed at 15-60 min after irradiation, with a rapid decrease at $120 \mathrm{~min}$ (Figure 1). The median tail intensities differed significantly up to and including the $60 \mathrm{~min}$ 
post-treatment time point $(p \leq 0.001)$. Afterwards, already after 120 and $360 \mathrm{~min}$ a rapid decrease was found. The same low intensities were observed before the second fraction, where median tail intensity was not significantly different from $\mathrm{T}_{0}$ anymore. (Table 1 and Figure 1 ).

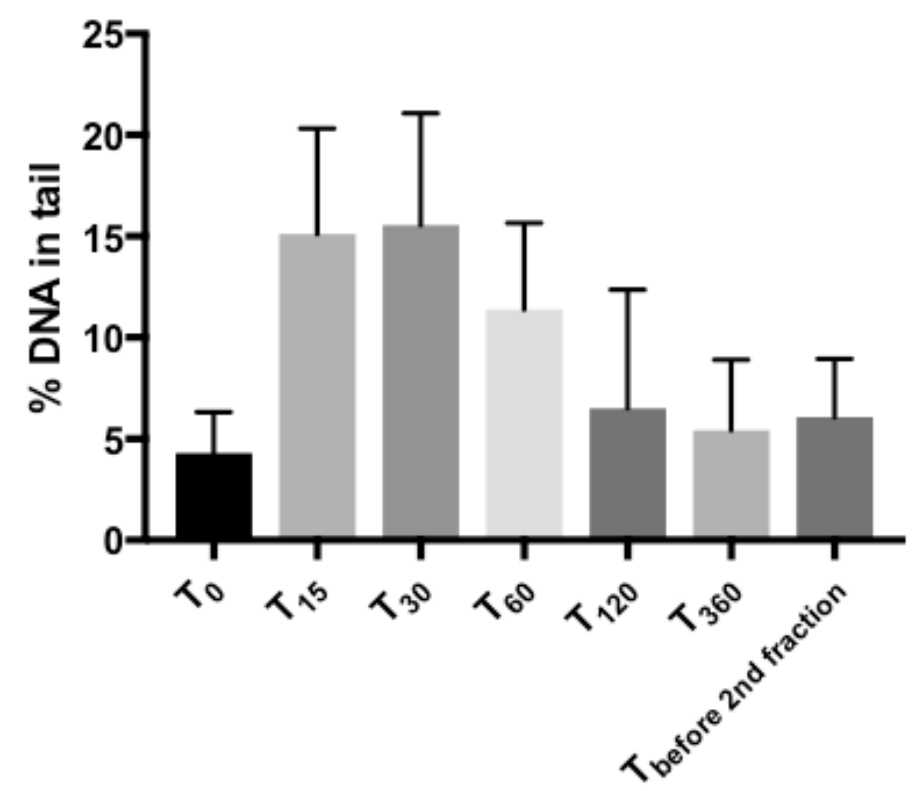

Figure 1. Time-course of DNA damage measured by comet assay. Tail intensity (\%DNA in tail) measured at indicated time-points after completion of radiation treatment $\left(\mathrm{T}_{0}\right.$-before treatment, $\mathrm{T}_{15}$, $\mathrm{T}_{30}, \mathrm{~T}_{60}, \mathrm{~T}_{120}, \mathrm{~T}_{360}$, minutes after treatment, respectively). Mean values $\pm \mathrm{SD}$ are shown. Significances in differences are displayed in Table 1.

Table 1. Differences of median tail intensity (\%DNA in tail), comet assay (\%; $95 \% \mathrm{CI}) . \mathrm{T}_{0}, \mathrm{~T}_{15}, \mathrm{~T}_{30}$, etc. indicate the time-points in minutes after completion of radiation treatment.

\begin{tabular}{ccc}
\hline Time-Points & Difference of \%DNA in Tail $\mathbf{( 9 5 \% ~ C I )}$ & $p$-Value \\
\hline $\mathrm{T}_{0} \rightarrow \mathrm{T}_{15}$ & $10.80(6.56 ; 15.04)$ & $p=0.001$ \\
$\mathrm{~T}_{0} \rightarrow \mathrm{T}_{30}$ & $11.24(6.38 ; 16.10)$ & $p=0.001$ \\
$\mathrm{~T}_{0} \rightarrow \mathrm{T}_{60}$ & $7.11(4.52 ; 9.71)$ & $p<0.001$ \\
$\mathrm{~T}_{0} \rightarrow \mathrm{T}_{120}$ & $2.47(-1.41 ; 6.36)$ & $p=0.172$ \\
$\mathrm{~T}_{0} \rightarrow \mathrm{T}_{360}$ & $1.24(-0.86 ; 3.33)$ & $p=0.185$ \\
$\mathrm{~T}_{0} \rightarrow \mathrm{T}_{\text {before 2nd fraction }}$ & $1.56(-0.87 ; 3.99)$ & $p=0.168$ \\
\hline
\end{tabular}

\subsection{Phosphorylated H2AX ( $\gamma H 2 A X)$ : Number of Positive Cells and Foci per Cell after Radiotherapy in} Tumor Samples

Samples from three time-points $\left(\mathrm{T}_{0}, \mathrm{~T}_{30}, \mathrm{~T}_{360}\right)$ of the included patients were analyzed for the number of positive cells (\%), as well as foci/cell (Figure 2). Both the amounts of positive cells as well as the numbers of foci per cell at $\mathrm{T}_{30}$ and $\mathrm{T}_{360}$ were significantly different from those at $\mathrm{T}_{0}(p<0.001$ for positive cells; $p=0.002$ for foci/cell). As shown in Table 2, both values had returned to baseline before the second fraction. The concurrently sampled co-irradiated normal tissue from the tumor patients followed the same pattern regarding the disappearance of foci (Figure 3). 

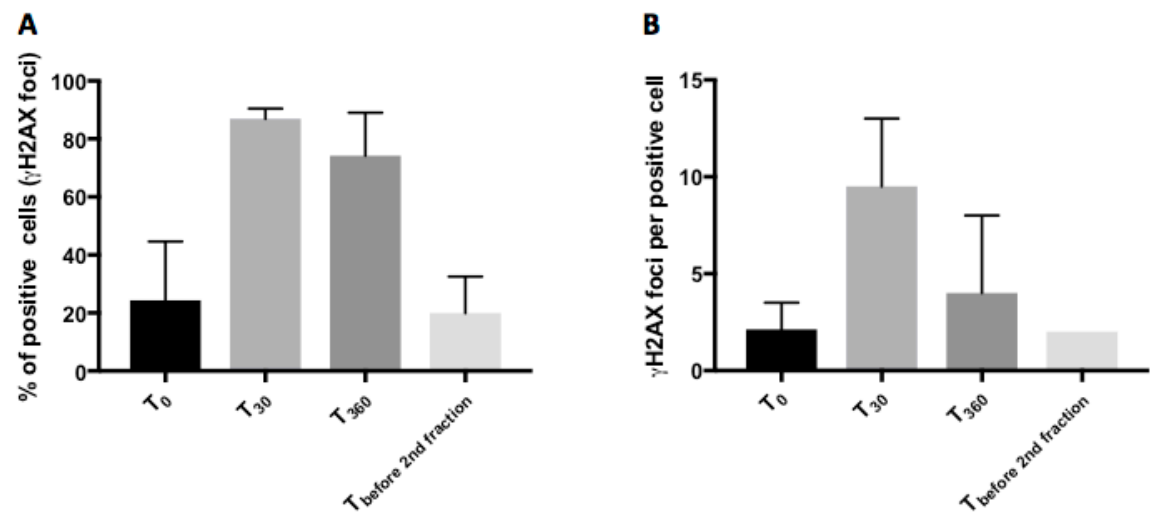

Figure 2. Staining for $\gamma \mathrm{H} 2 \mathrm{AX}$-foci before and after radiation treatment. Number of positive cells (\%) (A) and number of $\gamma \mathrm{H} 2 \mathrm{AX}$-foci per positive cell (B) before and at indicated time-points after completion of the treatment. Mean values \pm SD are shown.

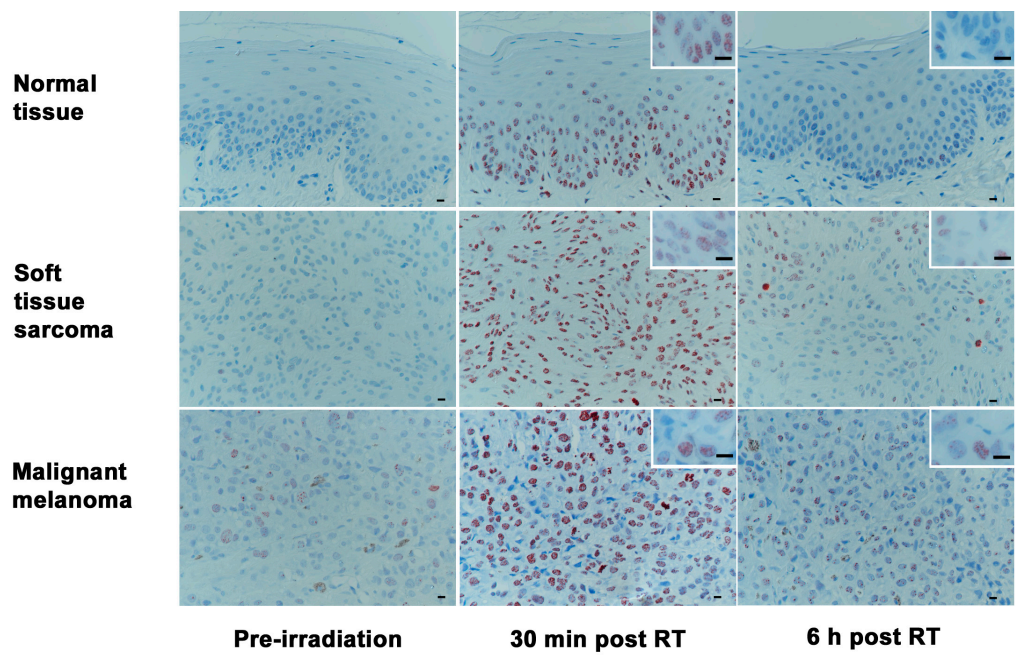

Figure 3. Time-course of $\gamma \mathrm{H} 2 \mathrm{AX}$ immunohistochemical labeling in normal epithelium, soft tissue sarcoma, and malignant melanoma. All tissues show low $\gamma \mathrm{H} 2 \mathrm{AX}$ reactivity before radiotherapy, high numbers of $\gamma \mathrm{H} 2 \mathrm{AX}$ positive cells and foci per cell at $30 \mathrm{~min}$ after radiotherapy, and a decrease of the respective numbers at $360 \mathrm{~min}$ after radiotherapy. (RT = radiotherapy; bars: overview $20 \mu \mathrm{m}$, insert $15 \mu \mathrm{m}$ ); (Immunoperoxidase, haematoxylin-conterstain: brown intranuclear dots represent $\gamma \mathrm{H} 2 \mathrm{AX}$-foci).

Table 2. (a) Positive staining for $\gamma \mathrm{H} 2 \mathrm{AX}$-foci (\%). $\mathrm{T}_{0}, \mathrm{~T}_{30}, \mathrm{~T}_{360}$, etc. indicate the time-points in minutes after completion of radiation treatment. (b) Number of $\gamma \mathrm{H} 2 \mathrm{AX}$-foci per positive cell. $\mathrm{T}_{0}, \mathrm{~T}_{30}, \mathrm{~T}_{360}$, etc. indicate the time-points in minutes after completion of radiation treatment.

\begin{tabular}{ccc}
\hline \multicolumn{3}{c}{$(\mathbf{a})$} \\
\hline Time-Points & Median $\boldsymbol{\gamma}$ H2AX Positive Cells $\mathbf{( \% ;}$;5\% CI) & $\boldsymbol{p}$-Value, Compared to $\mathbf{T}_{\mathbf{0}}$ \\
\hline $\mathrm{T}_{0}$ & $20.17(3.89 ; 62.36)$ & \\
$\mathrm{T}_{30}$ & $87.18(81.75 ; 91.78)$ & $p<0.001$ \\
$\mathrm{~T}_{360}$ & $78.48(41.88 ; 85.67)$ & $p=0.001$ \\
$\mathrm{~T}_{\text {before 2nd fraction }}$ & $15.61(9.80 ; 41.44)$ & \\
\hline & $(\mathbf{b})$ & \\
\hline Time-Points & Median $\boldsymbol{\gamma}$ H2AX-Foci Per Nucleus $\mathbf{( 9 5 \%} \mathbf{C I})$ & $\boldsymbol{p}$-Value, Compared to $\mathbf{T}_{\mathbf{0}}$ \\
\hline $\mathrm{T}_{0}$ & $2.13(2.00 ; 3.50)$ & $p<0.001$ \\
$\mathrm{~T}_{30}$ & $8.00(6.00 ; 15.00)$ & $p=0.002$ \\
$\mathrm{~T}_{360}$ & $4.00(3.00 ; 8.00)$ & $p=0.163$ \\
\hline $\mathrm{T}_{\text {before 2nd fraction }}$ & $2.00(2.00 ; 2.00)$ &
\end{tabular}




\subsection{Covariate Analysis}

Due to the time dependence, a linear mixed model approach was applied to detect associations between the median tail intensity, median positive cells, median foci/cell, and covariates such as age, gender, tumor volume, and cancer type. No influence of the covariates or the different fractions of serial measurement was detected.

\subsection{Baseline Levels of $\gamma H 2 A X$ in Tumor Biopsy Samples of Various Histologies}

Samples of various histologies (soft tissue sarcomas $(n=16)$, malignant melanomas $(n=19)$, carcinomas $(n=25)$, and malignant lymphomas $(n=23)$ ) were taken from patients undergoing surgical tumor removal for diagnostic or treatment purposes at the clinic (see Table 3 for patient-specific details). While the sampling groups did not vary in gender $(p=0.186)$, age $(p=0.014$, malignant lymphoma younger than malignant melanoma patients) and weight $(p=0.016$, soft tissue sarcomas heavier than malignant melanoma and carcinomas patients) showed some (clinically non-relevant) differences. Histologically, the malignant lymphoma tumor group had significantly higher values in foci/cell $(p<0.001)$ compared to the population with soft tissue sarcoma, malignant melanoma, or carcinomas (Figure 4). In terms of positive cells $(p=0.014)$, the malignant lymphoma tumor group had significantly higher values than the population with soft tissue sarcoma.

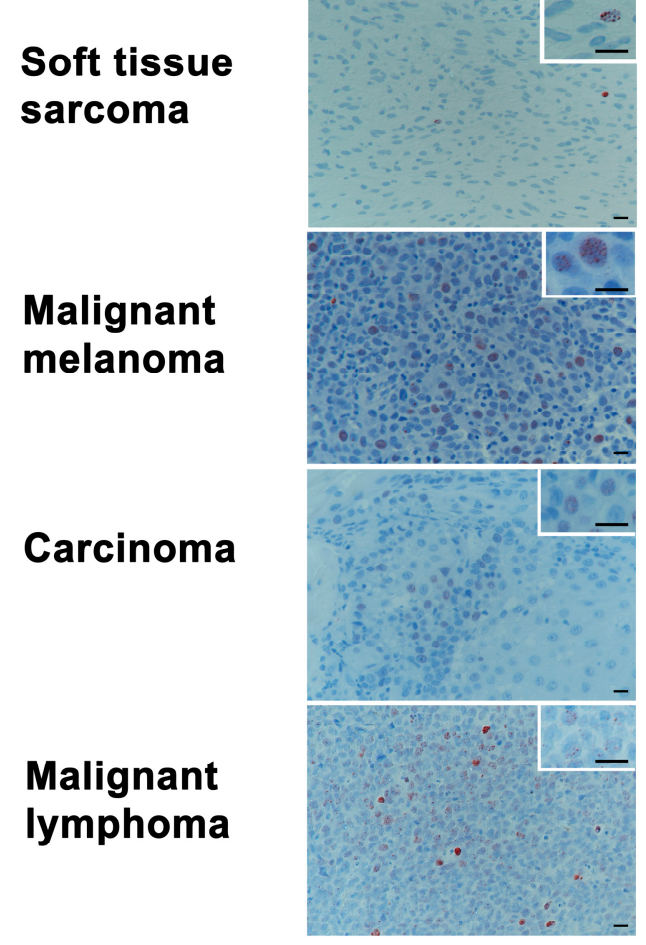

Figure 4. Examples of baseline levels $\gamma \mathrm{H} 2 \mathrm{AX}$ immunohistochemical labeling in indicated tumor types. (Bars: overview $20 \mu \mathrm{m}$, insert $15 \mu \mathrm{m}$ ); (Immunoperoxidase, haematoxylin-conterstain: brown intranuclear dots represent $\gamma \mathrm{H} 2 \mathrm{AX}$-foci). 
Table 3. Patient specific details for baseline values of $\gamma \mathrm{H} 2 \mathrm{AX}$ foci. $\mathrm{f}=$ female, $\mathrm{fs}=$ female spayed, $\mathrm{m}=$ male, $\mathrm{mn}=$ male neutered.

\begin{tabular}{|c|c|c|c|c|c|c|c|c|c|}
\hline Tumor Type & $\begin{array}{c}\text { Age (Years) } \\
\text { Mean (SD; Range) }\end{array}$ & $\begin{array}{c}\text { Weight (kg) } \\
\text { Mean (SD; Range) }\end{array}$ & Gender & $\begin{array}{l}\text { Median Positive } \\
\text { Cells (\%) }\end{array}$ & $95 \% \mathrm{CI}$ & $p$-Value & Median Foci/Tumor & $95 \% \mathrm{CI}$ & $p$-Value \\
\hline $\begin{array}{l}\text { Overall } \\
(n=83)\end{array}$ & $\begin{array}{l}9.89( \pm 2.92 ; \\
1.00-15.00)\end{array}$ & $\begin{array}{c}23.70( \pm 10.90 ; \\
3.60-55.00)\end{array}$ & $\begin{array}{c}\mathrm{f}=14 \\
\mathrm{fs}=27 \\
\mathrm{~m}=19 \\
\mathrm{mn}=23\end{array}$ & 20.72 & $21.88 ; 24.29$ & 0.014 & 2.50 & $2.40 ; 2.90$ & $<0.001$ \\
\hline $\begin{array}{l}\text { Soft tissue } \\
\text { sarcoma } \\
(n=16)\end{array}$ & $\begin{array}{l}9.74( \pm 1.80 ; \\
5.92-12.83\end{array}$ & $\begin{array}{l}30.40( \pm 9.88 \\
14.20-50.70)\end{array}$ & $\begin{array}{c}\mathrm{f}=3 \\
\mathrm{fs}=7 \\
\mathrm{~m}=3 \\
\mathrm{mn}=3\end{array}$ & 13.41 & $7.42 ; 20.59$ & & 2.00 & $1.50 ; 2.47$ & \\
\hline $\begin{array}{c}\text { Malignant } \\
\text { melanoma } \\
(n=19)\end{array}$ & $\begin{array}{l}11.71( \pm 2.59 \\
6.00-15.00)\end{array}$ & $\begin{array}{l}19.24( \pm 8.78 ; \\
3.60-30.50)\end{array}$ & $\begin{array}{c}\mathrm{f}=2 \\
\mathrm{fs}=4 \\
\mathrm{~m}=7 \\
\mathrm{mn}=6\end{array}$ & 15.35 & $12.25 ; 28.22$ & & 2.50 & $2.14 ; 2.99$ & \\
\hline $\begin{array}{l}\text { Carcinoma } \\
\quad(n=25)\end{array}$ & $\begin{array}{l}9.48( \pm 3.33 ; \\
1.00-15.00)\end{array}$ & $\begin{array}{c}20.79( \pm 10.23 \\
4.50-35.50)\end{array}$ & $\begin{array}{c}\mathrm{f}=6 \\
\mathrm{fs}=6 \\
\mathrm{~m}=8 \\
\mathrm{mn}=5\end{array}$ & 18.12 & $14.55 ; 28.67$ & & 2.00 & $2.03 ; 2.81$ & \\
\hline $\begin{array}{c}\text { Malignant } \\
\text { lymphoma } \\
(n=23)\end{array}$ & $\begin{array}{l}8.94( \pm 2.67 \\
3.58-13.75)\end{array}$ & $\begin{array}{l}25.88( \pm 11.04 ; \\
9.00-55.00)\end{array}$ & $\begin{array}{c}\mathrm{f}=3 \\
\mathrm{fs}=10 \\
\mathrm{~m}=1 \\
\mathrm{mn}=9\end{array}$ & 31.30 & $24.72 ; 34.93$ & & 3.00 & $2.87 ; 4.04$ & \\
\hline
\end{tabular}




\subsection{Quantification of the Time-Course of DNA Damage and Repair Using Novel Mathematical Modeling}

The evolutionary parameter search (based on the median \%DNA in tail) revealed a good fit to the in vivo data for the pooled sarcoma group time-course when both pathways (fast and slow) were active. In order to simplify the model, we tested the case where only the fast pathway was active. This fit had a larger error (Table 4) but in relation to the variability of the data (Figure 5A), it covered the experimental results reasonably well. Selected fits for time-courses of specific fractions are shown in Figure 5B-D. This more detailed display shows how pooling individual fractions and time-courses obtained from different patients can cover up a part of the heterogeneity of the in vivo data. As a consequence, the errors are generally larger than in pooled datasets. The data of the melanoma cases was deemed not suitable for similar analyses, as only time-courses of two patients irradiated at different fractionation schedules were available.
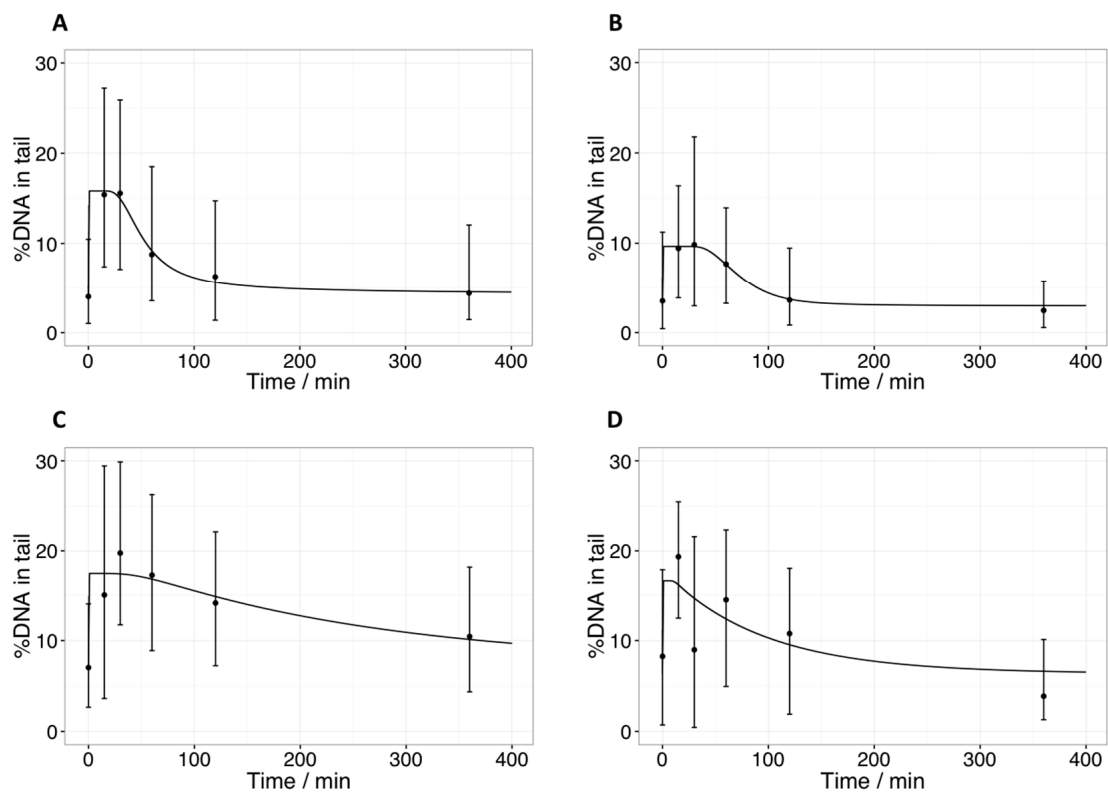

Figure 5. Time resolved comet data fitted by the bio-mathematical model. (A) Average of median $\%$ DNA in tail of all patients over three fractions for sarcoma cells, with only the fast repair pathway activated; (B) median \%DNA in tail for the first patient, fraction 1; (C) median \%DNA in tail for the second patient, fraction 1; (D) median \%DNA in tail for the second patient, fraction 2 . Error bars indicate upper and lower quartiles. The line represents the model prediction with parameters from Table 4 .

Table 4. Parameter sets of the bio-mathematical model for the sarcoma group. For the final repair step, second order kinetics was assumed and the data is given in \%DNA. The numbers in parentheses in column 1 (sarcoma, pooled) are for a fit of the full model; for the other values in this column, only one pathway is active. The remaining columns contain the fitted parameters of individual patient fractions.

\begin{tabular}{ccccc}
\hline Parameter & $\begin{array}{c}\text { Sarcoma, All Patients and } \\
\text { Fractions Pooled }\end{array}$ & $\begin{array}{c}\text { Patient 1, } \\
\text { Fraction 1 }\end{array}$ & $\begin{array}{c}\text { Patient 2, } \\
\text { Fraction 1 }\end{array}$ & $\begin{array}{c}\text { Patient 2, } \\
\text { Fraction 2 }\end{array}$ \\
\hline$k_{\text {cleav }} / \mathrm{min}^{-1}$ & $1.93(1.96)$ & 1.12 & 1.71 & 1.71 \\
$k_{0, \text { fast }} / \mathrm{min}^{-1}$ & $3.93 \cdot 10^{-1}\left(1.59 \times 10^{-1}\right)$ & $3.76 \times 10^{-2}$ & $4.35 \times 10^{-3}$ & $5.24 \times 10^{-2}$ \\
$k_{1, \text { fast }} / \mathrm{min}^{-1}$ & $2.92 \cdot 10^{-2}\left(3.44 \times 10^{-2}\right)$ & $2.55 \times 10^{-2}$ & $5.24 \times 10^{-2}$ & $1.39 \times 10^{-1}$ \\
$k_{2, \text { fast }} / \mathrm{min}^{-1}$ & $1.00 \cdot 10^{-2}\left(9.01 \times 10^{-3}\right)$ & $8.45 \times 10^{-2}$ & $2.65 \times 10^{-2}$ & 1.01 \\
$k_{0, \text { slow }} / \mathrm{min}^{-1}$ & $-\left(3.22 \times 10^{-3}\right)$ & - & - & - \\
$k_{1, \text { slow }} / \mathrm{min}^{-1}$ & $-\left(1.01 \times 10^{-3}\right)$ & - & - & - \\
$k_{2, \text { slow }} / \mathrm{min}^{-1}$ & $-\left(1.23 \times 10^{2}\right)$ & - & - & - \\
$t_{r, \text { slow }} / \mathrm{min}$ & $-(7.07)$ & - & - & 3.77 \\
$t_{r, \text { fast }} / \mathrm{min}^{\prime} / \% \mathrm{DNA}$ & $1.28 \cdot 10^{1}\left(1.09 \times 10^{1}\right)$ & $1.93 \times 10^{1}$ & $8.51 \times 10^{-1}$ & 6.35 \\
Error of fit & $4.23(4.09)$ & 2.94 & 7.12 & $6.97 \times 10^{1}$ \\
\hline
\end{tabular}




\section{Discussion}

Neither DNA damage induction, nor repair time-courses have been described from patients undergoing radiation therapy up to the present date. Hence, very little is known about the amount of actual DNA damage and the kinetics of repair in tumors in vivo, or in normal tissues under antineoplastic treatment. Herein, we used repeated samples from dogs with primary tumors undergoing therapeutic radiation therapy. Spontaneous tumors in companion animals like dogs are described to offer a unique opportunity as a model for human cancer biology and translational clinical research [15,16]. In contrast to most murine tumor xenograft studies, cancers in dogs arise over the background of an intact immune system and present many features like histological appearance, tumor genetics, molecular targets, biological behavior, and response to conventional therapies, as well as inter-patient tumoral heterogeneity common to humans [15]. Moreover, in many ways, a canine model serves even better than a murine one to study DNA damage repair (DDR) and its defects in vivo, as in rodents, certain repair pathways seem to be less active in comparison to the human mechanisms, displaying a potentially different emphasis and hierarchy of DNA repair pathways [17].

The intrinsic radiosensitivity of the tumor cells is a major determinant of the treatment response and outcome, and correlates with a patient's prognosis [18]. As summarized by McKenna et al., the comet assay technique has also been used in a wide range of human tumor cell lines as well as tissue biopsies and has shown predictive information value of the individual's sensitivity towards DNA damaging agents [13]. In the herein presented study, the kinetic median tail intensity (\%DNA in tail) showed a fast time-course, with no significant remaining differences in tail intensity after $120 \mathrm{~min}$ post-radiation in either soft tissue sarcoma or malignant melanoma samples. The alkaline comet assay was chosen because it is capable of detecting and quantifying effects of low, yet clinically relevant radiation doses of 0-6 Gy. Under alkaline conditions, DNA is denatured and both single strand breaks as well as double strand breaks are measured in the tail. In samples of human bladder cancer tissue irradiated ex vivo, evaluation for radiation induced DNA damage levels were measured by this method and the extent of comet formation was found to correlate with cell killing [6]. Furthermore, in this bladder cancer patient cohort, reduced DNA damage sensitivity was associated with poorer treatment outcomes, implying a clinical predictive potential for treatment-induced DNA damage detection with the alkaline comet assay in certain tumors $[6,19,20]$. However, the alkaline comet assays are able to detect both double and single strand breaks [21,22]. Hence, this assay also detects damage that is not necessarily directly responsible for cell death, as lethality is most frequently observed after non- or mis-repaired DSB. The neutral comet assay, on the other hand, can be modified to detect double strand breaks only, but this requires doses of radiation far higher than the clinically relevant ones. As a general advantage, the comet assay is a relatively inexpensive, simple, and fast technique that can be carried out on single-cell suspensions, and requires only a small number of cells [13]. This is in contrast to the more widely used clonogenic cell survival assay, which measures a surviving fraction of tumor cells after a given clinically relevant dose, but takes a number of weeks to be completed, for example, to obtain the results of clonogenicity of the tumor cells [23]. Showing a strong correlation between the methods of clonogenic survival and alkaline comet assay at clinically relevant doses in tumor cell lines, these measurements of initial as well as residual DNA damage can probably be used to predict radiation sensitivity in patient derived tumor cells as well $[19,20,24]$.

Prior work-including in vivo mouse assays with various cell lines of head and neck carcinoma, as well as in ex vivo assays using different tumor types from patients-has documented radioresponsiveness in sensitive and resistant tumor types to be represented by residual $\gamma \mathrm{H} 2 \mathrm{AX}$-foci $[1,2,5]$. After antineoplastic treatment, the initiation of DNA repair by the two major responsible pathways is triggered by the phosphorylation of the histone protein $\mathrm{H} 2 \mathrm{AX}$, which leads to formation of $\gamma \mathrm{H} 2 \mathrm{AX}$-molecules at the site of the DSB $[4,25,26]$. Upon repair, the $\gamma \mathrm{H} 2 \mathrm{AX}$-foci will disappear over a time-course, mostly in concert with DSB rejoining, but it is also suggested that a part of foci removal depends on subsequent steps of DSB rejoining [25,27]. Several reports describe the induction and decline of $\gamma \mathrm{H} 2 \mathrm{AX}$ foci in vitro [28-31], and also in cancer and normal tissues irradiated 
in/ex vivo $[2,5,32,33]$. It has been reported that $\gamma \mathrm{H} 2 \mathrm{AX}$ foci number in bone marrow cells of mice irradiated with 4 Gy peaked at $1 \mathrm{~h}$ after treatment and decreased to baseline already after $4 \mathrm{~h}$, while, in contrast, $\gamma \mathrm{H} 2 \mathrm{AX}$ foci were still present in irradiated spermatocytes and round spermatid after $48 \mathrm{~h}$ [33]. The kinetics of foci induction and disappearance depends on the dose of ionizing radiation, intrinsic cellular radiosensitivity, cell cycle phase and DNA content, the baseline levels of $\gamma \mathrm{H} 2 \mathrm{AX}$, and, furthermore, on microenvironmental conditions such as tissue oxygen concentration [34]. In accordance with our observations, there is a general pattern of acute increase right after irradiation (5-30 min) with decrease between $0.5 \mathrm{~h}$ and $24 \mathrm{~h}$ after irradiation, depending on the type of tissue or cells [35]. As a common finding in cultured cancer cells as well as in malignant human tumors of different origins, untreated canine cancers also contain elevated levels of spontaneous $\gamma \mathrm{H} 2 \mathrm{AX}$-foci, which are thought to represent inherent genomic instability [30]. The overall median number of 2.5 foci per cell found herein, ranging from 1.5-2.5 in soft tissue sarcomas to 2.9-4 in malignant lymphoma (e.g., high-grade non-Hodgkin's lymphoma) was within the range of 1-20 foci per cell described in human cancers and various canine cell lines [30,36]. In line with our data, other recent reports show continuous activation of DNA-repair pathways and constitutive expression of $\gamma \mathrm{H} 2 \mathrm{AX}$ in human diffuse large B-cell lymphoma [28,37].

The bio-mathematical model chosen can be used to describe the comet assay derived data for sarcoma, even when only one pathway is assumed to be active. The evolutionary parameter search seems to be very sensitive to the constraints set for the optimization runs. In contrast to other models [38,39], the model used in this work summarizes the different steps in a repair pathway by a delayed process. The consequence of this approach is, on one hand, a reduction of parameters but, on the other hand, a model containing Delay Differential Equations (DDE), which makes the evolutionary parameter search more difficult. The interpretation of parameter values derived by fitting the comet data in this work remains challenging at this point, as they vary over several orders of magnitude. The time delays found range from less than one minute (patient 2, fraction 1) to almost 20 min (patient 1, fraction 1), for example. Yet, based on the plots shown in Figure 5 and the large variability in the data, the derived values seem plausible. A better aggregation of parameter values may be reached (1) by modeling distributions instead of relying on median values, and (2) by improving time resolution, especially at the time-point of $240 \mathrm{~min}$. The comparison with time-resolved $\gamma \mathrm{H} 2 \mathrm{AX}$ foci signals may be another option; however, the decay of $\gamma \mathrm{H} 2 \mathrm{AX}$ foci is slower, possibly due to remaining residues of attached ATM after DNA strands are joined, and therefore could mask the real dynamics of repair (e.g., the time-course of DSB elimination) [40]. In order to optimally distinguish between Homologous Recombination (HR)- and Non-Homologues End-Joining (NHEJ)-pathways, time resolved data from specific markers such as RAD51 for HR, and 53BP1 for NHEJ should be included in the model. To gain deeper insight into the full dynamics of the involved repair processes, dose-rate dependent data could also be included, representing a general limitation of using material from patients with spontaneous tumors. A thorough characterization from in vivo samples is more difficult compared to well-defined cell lines treated in vitro.

In this study, after a first data screening, we decided to average the data of sarcoma patients for the initial modeling. One has to keep in mind that differences in intrinsic radiosensitivity in tumors of the same histological origin exist and can be notable [30,41,42]. It is therefore important not only to investigate the pooled time-course (Figure 5A), but to also review the data before pooling (Figure 5B-D). Thereby, a considerable heterogeneity in the time-courses can be revealed, in particular between fractions of the same patient. While the time-course shown in Figure 5B resembles a scaled version of the pooled time-course, the one shown in Figure 5C is much slower. Furthermore, the median $\% D N A$ in tail at $\mathrm{T}_{30}$ is higher than the one at $\mathrm{T}_{15}$. Since damage is only induced during irradiation and is then assumed to decrease, the model cannot produce such a time-course. Instead, parameter estimates are found that yield a prediction between those two median values. While the variation in medians between $T_{15}$ and $T_{30}$ is well within the range of the error, the discrepancy between the medians and the model prediction lead to an increased error of fit. Figure 5C shows another fraction 
of the same patient, again presenting a different time-course with a shorter delay and faster decay. The median at $T_{30}$ is low compared to the surrounding medians, resulting in an even larger error of fit. As a limitation of the study, the time-courses from a limited number of patients presented herein do not allow any conclusions to be drawn on individual radioresponsiveness or prognostic relevance of these findings. As a further general limitation of this in vivo approach, minimally invasive and repetitive tumor sampling bears the risk of a mis-representation of the tumor as a whole, due to intra-tumoral heterogeneity in the extent and distribution of malignancy, stromal reaction, inflammatory cells, necrosis, and hypoxia. The sampling heterogeneity with fine needle aspirates and subsequent comet assay might falsely reflect the intrinsic radiosensitivity or repair capacity of a certain area, and manipulation of single tumor cells and tissues can induce further sampling error. Sanguineous contamination may occur, leading to measurement errors with very high DNA intensities in the comet tail, an intensity error that can also be produced by early apoptotic cells [13,43]. Concurrent microscopic evaluations of FNA samples are recommended to assess the representativeness of a sample. These limitations, however, reflect the clinical situation in any predictive testing for individual patients with the goal of personalized medicine and cannot be completely circumvented. However, in patient sample dependent mathematical data modeling, they can be in part attenuated by choosing a high time resolution and large individual sample size.

At early time-points after RT, quantification of $\gamma \mathrm{H} 2 \mathrm{AX}$ foci was impaired due to foci overlap. This is a phenomenon that is also problematic for immunofluorescent staining and computerized quantification. In our evaluation, samples with foci numbers higher than 10 were adjusted as " 25 foci" per cell. This was the case in samples taken $30 \mathrm{~min}$ and $6 \mathrm{~h}$ after irradiation. Furthermore, there is an ongoing debate in the literature regarding what should be considered as foci, which is also related to certain subjectivity in manual scoring [44].

In conclusion, we confirm the clinical feasibility of repeated in vivo minimally invasive sampling with FNA as well as small biopsies in order to quantify the amounts and time-courses of DNA damage produced by therapeutic RT. Both dynamics of comet tail intensity and $\gamma \mathrm{H} 2 \mathrm{AX}$-foci could be tracked during a course of radiation and the resulting data could be integrated into a dynamic mathematical model for DNA damage formation and repair. By evaluating not only initial or residual DNA damage, but following a time-course of an individual patient, DNA repair can be quantitatively described.

\section{Materials and Methods}

The current investigation involved samples of canine tumor patients with various types of cancers. In repeated samples from patients treated with RT, DNA damage formation and repair was assessed with comet assay (an assay used to investigate DNA damage in human biomonitoring and genotoxicology) [11-13] and $\gamma \mathrm{H} 2 \mathrm{AX}$ immunohistochemistry (representing an early event after double-strand break formation) [14,45] at defined time points. The resulting findings were then integrated into the bio-mathematical repair-pathway model in order to perform a model-based analysis of comet data. Additionally, biopsies of various tumors were screened with immunohistochemistry for the amount of pre-treatment $\gamma \mathrm{H} 2 \mathrm{AX}$ levels in order to define a baseline of DNA damage in canine tumors.

\subsection{Patients and Sampling Procedures}

Dogs presented to the Division of Radiation Oncology, Vetsuisse Faculty, University of Zurich, Switzerland for treatment of bulky malignant tumors between March 2014 and December 2015 were included in the study. Each dog had a clinical work up (tumor staging) as appropriate to the type of presenting disease. Written owner's consent was obtained for invasive sampling in this study. This study was carried out in strict accordance with the recommendations and the protocol approved by the Animal Ethics Council of the Canton of Zurich, Switzerland (Permit Numbers: 180/2011, 7 December 2011) and (ZH108/15, 14 January 2016). All invasive sampling procedures were performed under anesthesia, and all efforts were made to minimize suffering. In addition, in order to investigate 
the basal level of $\gamma \mathrm{H} 2 \mathrm{AX}$, a series of tumor biopsy samples of various histologies (soft tissue sarcomas, malignant melanomas, carcinomas, and lymphomas) were taken from patients undergoing surgical tumor removal for diagnostic or treatment purposes at the clinic.

For comet assay analysis, tumor cells were collected with a minimally invasive method using fine-needle aspiration (FNA): Sampling was performed with a 5-mL syringe attached to a 22-gauge needle as previously described [46]. The aspirated volume of $10 \mu \mathrm{L}$ was immediately mixed with a freezing solution of $440 \mu \mathrm{L}$ fetal calf serum (FCS, Gibco, Thermo Fisher Scientific, Reinach, Switzerland) and $50 \mu \mathrm{L}$ dimethyl sulfoxide (DMSO, Sigma-Aldrich, Buchs, Switzerland) in pre-cooled cryotubes. Cryotubes were stored at $-80^{\circ} \mathrm{C}$ until a comet assay was performed. FNA samples from the tumor site were taken in duplicates $15 \mathrm{~min}$ before RT and 15, 30, 60, $120 \mathrm{~min}$, and $6 \mathrm{~h}$ after RT during the multiple fractions of radiotherapy.

Tumor biopsies for $\gamma \mathrm{H} 2 \mathrm{AX}$ immunohistochemistry were collected using 12-gauge Bard ${ }^{\circledR}$ Biopty-Cut ${ }^{\circledR}$ Disposable Core Biopsy Needles, and normal, co-irradiated tissue was sampled with $4 \mathrm{~mm}$ punches. Tissue was fixed for $24 \mathrm{~h}$ in $10 \%$ buffered formalin and embedded into paraffin wax by routine methods. Samples were taken $15 \mathrm{~min}$ before, and $30 \mathrm{~min}$ and $6 \mathrm{~h}$ after RT treatment.

\subsection{Treatment}

Radiation was delivered with a 6 megavolt (MV) linear accelerator (Clinac iX, Varian, Palo Alto, CA, USA) using either photons or electrons, depending on tumor size and location. Treatment planning was performed on the basis of computer tomography (CT) for photon plans or by hand calculation for electron plans. During treatment, dogs were under general anesthesia using propofol for induction of anesthesia and sevoflurane for maintenance of anesthesia, immobilized in an individually shaped vacuum cushion, and, if required, additionally equipped with a custom-made bite block. The recommendations for specifying dose and volumes as proposed for veterinary medicine were adhered to as proposed in the corresponding literature. The prescribed dose was $30 \mathrm{~Gy}$, delivered in five fractions of 6 Gy applied twice per week, resulting in an overall treatment time of 2.5 weeks [47-49].

\subsection{Alkaline Comet Assay}

After thawing, the FNA samples were mixed with $9 \mathrm{~mL}$ of ice-cold phosphate-buffered saline (PBS) and centrifuged for $10 \mathrm{~min}\left(1500 \mathrm{rpm}, 4^{\circ} \mathrm{C}\right)$. The pellet was re-suspended in $100 \mu \mathrm{L}$ of ice-cold PBS. A volume corresponding to approximately 170,000 cells was mixed with $90 \mu \mathrm{L}$ of agarose (1\% low melting point agarose (LMPA, Trevigen, Gaithersburg, MA, USA) in PBS, $37^{\circ} \mathrm{C}$. Subsequently, $25 \mu \mathrm{L}$ of agarose-cell solution was pipetted onto 20-well slides (Trevigen, Gaithersburg, MA, USA) in duplicate. The loaded slides were then placed at $4{ }^{\circ} \mathrm{C}$ for $5 \mathrm{~min}$ to allow agarose polymerization, and subsequently placed in lysis buffer for $1 \mathrm{~h}$ at $4{ }^{\circ} \mathrm{C}$, followed by incubation twice in ice-cold alkaline electrophoresis solution ( $\mathrm{pH}>13.0$ ) for $10 \mathrm{~min}$ at $4{ }^{\circ} \mathrm{C}$ in the dark. After electrophoresis ( $300 \mathrm{~mA}, 15-20 \mathrm{~min}$ ), the slides were incubated twice for $10 \mathrm{~min}$ in $\mathrm{dH}_{2} \mathrm{O}$ at room temperature, followed by incubation in $70 \%$ ethanol for $5 \mathrm{~min}$ at room temperature in the dark. After complete drying, $70 \mu \mathrm{L}$ of diluted SYBR-Green (1:10,000 in TE, $\mathrm{pH} 8)$ was pipetted on every well, and the slides were incubated for $15 \mathrm{~min}$ in the dark. The slides were washed twice for $10 \mathrm{~min}$ in $\mathrm{dH}_{2} \mathrm{O}$ at room temperature. To provide a quantitative analysis of obtained comets (\%DNA in tail, tail intensity), the COMET IV ${ }^{\circledR}$ scoring system was used.

\section{4. $\gamma H 2 A X$ Immunohistochemistry}

Information about antibodies, pretreatment, incubation conditions, and visualization are reported in Table 5. For immunohistochemical staining, a Dako Autostainer (Dako, Baar, Switzerland) was used. Three-micrometer $(3-\mu \mathrm{m})$ sections were mounted on positively charged slides (Superfrost Plus, Thermo Fisher Scientific, Reinach, Switzerland), dried overnight at $37^{\circ} \mathrm{C}$, deparaffinized, rehydrated, and immersed for $10 \mathrm{~min}$ in 10\% hydrogen peroxide to block endogenous peroxidase activity. Antibody diluent (S2022) and wash buffer (S3006) from Dako (Baar, Switzerland) were used. Negative controls were done omitting the primary antibody. 
Table 5. Antibodies and incubation conditions. Primary antibody, treatment, and incubation conditions,

${ }^{*}$ HIER $=$ heat - induced epitope retrieval, carried out in a steamer (Pascal S2800, Dako).

\begin{tabular}{cccccccc}
\hline Antigen & Vendor & $\begin{array}{c}\text { Antibody } \\
\text { Type }\end{array}$ & $\begin{array}{c}\text { Catalogue } \\
\text { No./Clone }\end{array}$ & $\begin{array}{c}\text { Dilution, } \\
\text { Incubation } \\
\text { Conditions }\end{array}$ & Pre-Treatment & $\begin{array}{c}\text { Visualization } \\
\text { Method }\end{array}$ & $\begin{array}{c}\text { Positive } \\
\text { Control }\end{array}$ \\
\hline$\gamma \mathrm{H} 2 \mathrm{AX}$ & $\begin{array}{c}\text { Millipore } \\
\text { Temecula, } \\
\text { CA, USA }\end{array}$ & $\begin{array}{c}\text { mouse } \\
\text { mAb, IgG1 }\end{array}$ & $\begin{array}{c}05-0636 / \text { clone } \\
\text { JBW301 }\end{array}$ & $\begin{array}{c}1: 200,1.3 \mathrm{~h}, \text { room } \\
\text { temperature }\end{array}$ & $\begin{array}{c}\mathrm{HIER} * 20 \mathrm{~min} \\
98^{\circ} \mathrm{C}, \text { citrate } \\
\text { buffer } \mathrm{pH} 6.0\end{array}$ & $\begin{array}{c}\text { Envision Kit } \\
\text { (Dako) }\end{array}$ & $\begin{array}{c}\text { Irradiated } \\
\text { canine tumor } \\
\text { tissue }\end{array}$ \\
\hline
\end{tabular}

The quantification of $\gamma \mathrm{H} 2 \mathrm{AX}$ positively stained cells and $\gamma \mathrm{H} 2 \mathrm{AX}$ foci was performed by manual counting by one investigator (NS) after reaching internal consensus on the procedure. The tumor slides were scanned and analyzed with NanoZoomer 2.0-HT scanscope (Hamamatsu, CH-4500 Solothurn) and visualized using the NDP.view2 software (Hamamatsu). For each tumor, 10 fields of identical size $(50 \times$ magnification) were set randomly, but dispersed over non-necrotic tumor areas. Furthermore, in each tumor, the number of $\gamma \mathrm{H} 2 \mathrm{AX}$ foci were counted in the nuclei of 300 cells.

\subsection{Bio-Mathematical Modeling}

For the bio-mathematical model, the following initial assumption was made: DNA breaks can be processed by (1) a fast repair pathway reflecting Non-Homologues End-Joining (NHEJ) for DSB or SSB-repair by PARP-1/XRCC1/DNA repair module, which may also be involved in the DSB repair by the B-NHEJ backup pathway [50] or by (2) a slower repair pathway (Homologous Recombination (HR) for DSB). Due to the lack of pathway-specific markers in this study, we cannot allocate the two pathways of the model to either HR and/or NHEJ repair mechanisms. We therefore named the two pathways slow and fast, leaving their connection to HR and NHEJ open. Since SSB is also observable in an alkaline comet assay, it can be expected that DNA-fragments produced by direct DSB will be flanked by those initially produced by SSB. The decision to start with the described two pathways was biologically motivated and based on a preliminary analysis of the comet data from melanoma (data not shown). We found that the two-pathway model did not bear significant advantages over a one-pathway model for the sarcoma data. In particular, the two-pathway model failed to reveal two co-existing repair processes. The parameters resulting from the fitting procedure suggest that one pathway dominates (see Table 4). The model was thus simplified to a one-pathway model by forcing the reaction rates of the slow pathway to 0 . Due to the symmetry in the model, this is equivalent to setting the fast pathway to 0 . After this simplification, the term fast lost its meaning, as only one pathway remains in this model. This entails a modest increase in error of fit due to the loss of four parameters. In Figure 6, a flow chart for the two-pathway model is shown: DNA damages (number $n_{0}$; including SSB and DSB) are produced with an induction rate proportional to the dose rate $R\left(d n_{0} / d t=k_{\text {cleav }} R\right.$; $k_{\text {cleav }}$ is a cleavage constant). Since there is a large number of remaining potential target sites (DNA fragments in tail typically below $25 \%$ ), it is assumed that there is no saturation effect. It has to be pointed out here that this is a simplistic approach for fragment generation. Since a fragment will be cut out of a DNA strand by two hits, one would expect an additional dependence of the absorbed dose $D$ at the corresponding time $t: d n_{0} / d t=k_{\text {cleav }} R \cdot D$. In addition, pre-existing, non-radiation induced breaks can lead to the liberation of a fragment when a second, radiation-induced break will occur. This process is then, as initially assumed, simply proportional to the dose rate. Both possibilities combined will yield $d n_{0} / d t=k_{\text {cleav }} R \cdot(\varepsilon+D)$, where $\varepsilon$ is a dose-equivalent for pre-existing, not-radiation induced breaks. Simulations with the different models and varying parameter values for $\varepsilon$ resulted only in different values for $k_{\text {cleav }}$ without significant impact on the terminal course of the number of fragments in the tail. Since the number of data points is limited and experiments were performed at only one dose rate, we decided to use the simplest approach for fragment generation in this study.

The primary damages $\left(n_{0}\right)$ can be detected by one of the two repair pathways and then transformed to damages prepared for the fast $\left(n_{1, \text { fast }}\right)$ or the slow $\left(n_{1, \text { slow }}\right)$ pathway. For this process, first order kinetics are assumed with reaction rate constants $k_{0, \text { fast }}$ and $k_{0, s l o w}$, respectively. After 
detection by a repair-pathway, the damages are processed and prepared for end-joining, or in the case of HR, homology search. This process is also assumed to be of first order with reaction rates $k_{1, f a s t}$ and $k_{1, \text { slow }}$, delayed by $t_{r, \text { fast }}$ and $t_{r, \text { slow }}$, respectively. The amount (number) of processed damages is denoted by $n_{2, \text { fast }}$ and $n_{2, \text { slow }}$, respectively. The damages are finally repaired by a second-order process. It is further assumed that all types of damages $\left(n_{0}, n_{1, \text { fast }}, n_{1, \text { slow }}, n_{2, \text { fast }}, n_{2, \text { slow }}\right)$ can be transported by electrophoresis and are therefore visible in the comet tail. The total amount of damage predicted by the model is the sum of all damages $n_{i}$ along with a baseline value $b_{n}$ that is co-evolved during optimization. Free DNA fragments fade away by the final repair process step at rates of $k_{2, \text { fast }}$ and $k_{2, \text { slow }}$, respectively. This process is described by second order kinetics in the model, since two fragments are joined together. The full set of equations of the mathematical model and parameter values is given in the supplementary materials.

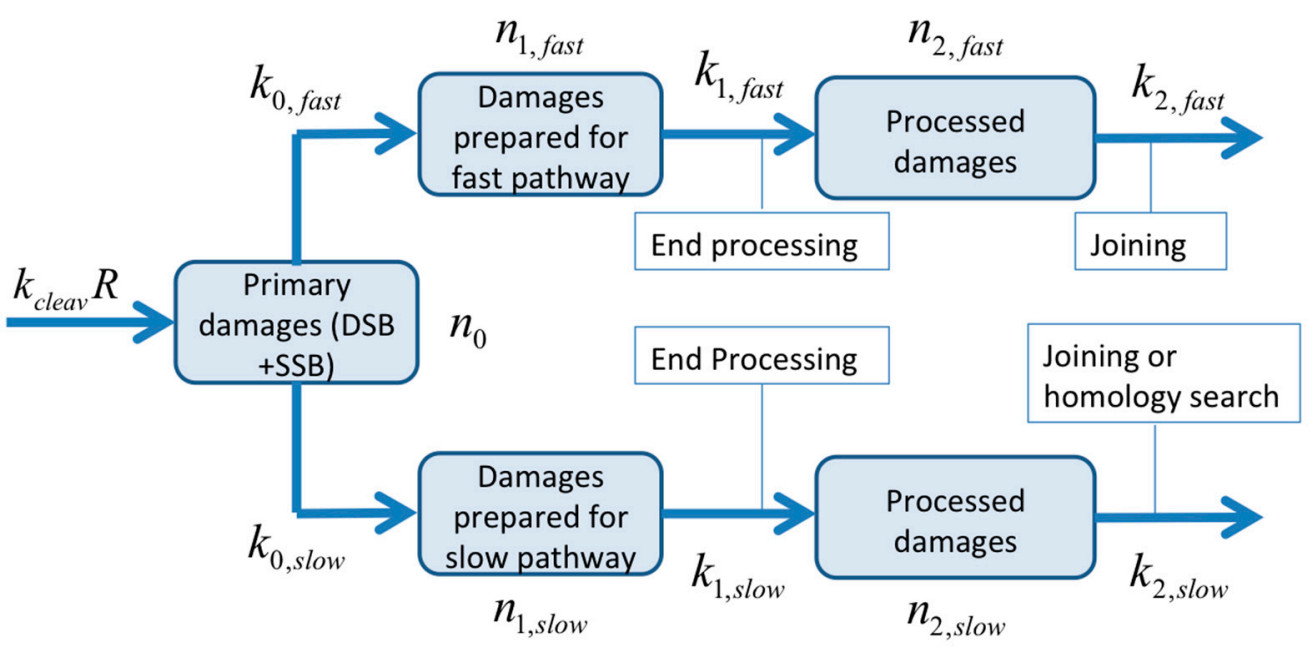

Figure 6. Process flow chart for the two-pathway model. Primary damages $\left(n_{0}\right)$ are detected by one of the two repair pathways and then transformed to damages prepared for the fast $\left(n_{1, \text { fast }}\right)$ or slow $\left(n_{1, \text { slow }}\right)$ pathway (by a first order kinetics). The damages are further processed and prepared for end-joining, or in the case of HR, homology search. Processed DNA fragments $\left(n_{2, \text { fast }}\right.$ and $\left.n_{2, \text { slow }}\right)$ fade away by the final repair step (second order kinetics). The full set of equations of the mathematical model is given in the supplementary materials.

For the model-based analysis, the median values of \%DNA fragments in comet tail have been calculated. To determine the parameter values in the model, an evolutionary optimization algorithm using a gradient search method was applied [39].

\subsection{Statistical Methods}

Data were coded in Excel and analyzed with SPSS version 21. Descriptive statistics such as means, standard deviations, medians, interquartile ranges (IQRs) together with corresponding 95\% confidence intervals (95\% CIs) were computed. The non-parametric Spearman correlations for associations between two continuous variables were computed. Due to the time dependence, a linear mixed model approach was applied to detect associations between the comet median tail intensity in $\%(0,15,30,60$, $120,360 \mathrm{~min}$ after RT and compared to the beginning of the next fraction), median $\gamma \mathrm{H} 2 \mathrm{AX}$ positive stained cells in \%, median number of $\gamma \mathrm{H} 2 \mathrm{AX}$ foci per cell $(0,30,360 \mathrm{~min}$ after $\mathrm{RT}$ and compared to the beginning of the next fraction) adjusted for the following predictors: age, gender, tumor volume, and histological group.

For the analysis of the baseline levels of $\gamma \mathrm{H} 2 \mathrm{AX}$ in tumor biopsy samples of various histologies, the Kolmogorov-Smirnov test was applied to check the correctness of normality assumption of the median $\gamma \mathrm{H} 2 \mathrm{AX}$ positive stained cells in $\%$ and median number of $\gamma \mathrm{H} 2 \mathrm{AX}$ foci per cell. The one-way 
ANOVA together with the Scheffé post-hoc test approach was taken to investigate differences in primary outcomes of median $\gamma \mathrm{H} 2 \mathrm{AX}$ positive stained cells in $\%$ and median number of $\gamma \mathrm{H} 2 \mathrm{AX}$ foci in the nucleus, age, and weight with respect to diagnostic code. The association between the diagnostic code and gender was checked with the $\mathrm{Chi}^{2}$-test. Results of statistical analysis with $p$-value $<5 \%$ were interpreted as statistically significant.

Supplementary Materials: Supplementary materials can be found at www.mdpi.com/1422-0067/18/6/1176/s1.

Acknowledgments: Funding was provided by the Marie-Louise von Muralt Stiftung fuer Kleintiere, Zurich, Switzerland-Carla Rohrer Bley; Krebsliga Zurich, Switzerland-Carla Rohrer Bley; Swiss Life Jubilee foundation, Zurich-Hassan Chaachouay; Swiss National Foundation (grant number 320030_163435)-Stephan Scheidegger.

Author Contributions: Nadine Schulz, Hassan Chaachouay, Katarzyna J. Nytko, Mathias S. Weyland, Stephan Scheidegger, and Carla Rohrer Bley wrote the manuscript. Nadine Schulz and Carla Rohrer Bley enrolled the patients and collected the samples. Nadine Schulz, Hassan Chaachouay, Katarzyna J. Nytko, Mathias S. Weyland, Franco Guscetti, Malgorzata Roos, Rudolf M. Füchslin and Stephan Scheidegger analyzed the data. Hassan Chaachouay conceived and carried out the comet assay, and conceived the $\gamma$-H2AX analysis. Hassan Chaachouay, Stephan Scheidegger and Carla Rohrer Bley conceived of the study, and participated in its design and coordination. All authors contributed to and approved the final version of the manuscript.

Conflicts of Interest: The authors declare no conflict of interest.

\section{References}

1. Koch, U.; Hohne, K.; von Neubeck, C.; Thames, H.D.; Yaromina, A.; Dahm-Daphi, J.; Baumann, M.; Krause, M. Residual $\gamma \mathrm{H} 2 \mathrm{AX}$ foci predict local tumour control after radiotherapy. Radiother. Oncol. 2013, 108, $434-439$. [CrossRef] [PubMed]

2. Menegakis, A.; de Colle, C.; Yaromina, A.; Hennenlotter, J.; Stenzl, A.; Scharpf, M.; Fend, F.; Noell, S.; Tatagiba, M.; Brucker, S.; et al. Residual $\gamma \mathrm{H} 2 \mathrm{AX}$ foci after ex vivo irradiation of patient samples with known tumour-type specific differences in radio-responsiveness. Radiother. Oncol. 2015, 116, 480-485. [CrossRef] [PubMed]

3. Menegakis, A.; Yaromina, A.; Eicheler, W.; Dorfler, A.; Beuthien-Baumann, B.; Thames, H.D.; Baumann, M.; Krause, M. Prediction of clonogenic cell survival curves based on the number of residual DNA double strand breaks measured by $\gamma \mathrm{H} 2 \mathrm{AX}$ staining. Int. J. Radiat. Biol. 2009, 85, 1032-1041. [CrossRef] [PubMed]

4. Wouters, B.G.; Begg, A.C. Irradiation-induced damage and the DNA damage response. In Basic Clinical Radiobiology, 4th ed.; Joiner, M., Van der Kogel, A., Eds.; CRC Press: Boca Raton, FL, USA, 2009; pp. 11-26.

5. Menegakis, A.; von Neubeck, C.; Yaromina, A.; Thames, H.; Hering, S.; Hennenlotter, J.; Scharpf, M.; Noell, S.; Krause, M.; Zips, D.; et al. $\gamma \mathrm{H} 2 \mathrm{AX}$ assay in ex vivo irradiated tumour specimens: A novel method to determine tumour radiation sensitivity in patient-derived material. Radiother. Oncol. 2015, 116, 473-479. [CrossRef] [PubMed]

6. Bowman, K.J.; Al-Moneef, M.M.; Sherwood, B.T.; Colquhoun, A.J.; Goddard, J.C.; Griffiths, T.R.; Payne, D.; Singh, S.; Butterworth, P.C.; Khan, M.A.; et al. Comet assay measures of DNA damage are predictive of bladder cancer cell treatment sensitivity in vitro and outcome in vivo. Int. J. Cancer 2014, 134, 1102-1111. [CrossRef] [PubMed]

7. Lord, C.J.; Ashworth, A. Bringing DNA repair in tumors into focus. Clin. Cancer Res. 2009, 15, 3241-3243. [CrossRef] [PubMed]

8. Graeser, M.; McCarthy, A.; Lord, C.J.; Savage, K.; Hills, M.; Salter, J.; Orr, N.; Parton, M.; Smith, I.E.; Reis-Filho, J.S.; et al. A marker of homologous recombination predicts pathologic complete response to neoadjuvant chemotherapy in primary breast cancer. Clin. Cancer Res. 2010, 16, 6159-6168. [CrossRef] [PubMed]

9. Li, W.; Li, F.; Huang, Q.; Shen, J.; Wolf, F.; He, Y.; Liu, X.; Hu, Y.A.; Bedford, J.S.; Li, C.Y. Quantitative, noninvasive imaging of radiation-induced DNA double-strand breaks in vivo. Cancer Res. 2011, 71, 4130-4137. [CrossRef] [PubMed]

10. Somaiah, N.; Yarnold, J.; Daley, F.; Pearson, A.; Gothard, L.; Rothkamm, K.; Helleday, T. The relationship between homologous recombination repair and the sensitivity of human epidermis to the size of daily doses over a 5-week course of breast radiotherapy. Clin. Cancer Res. 2012, 18, 5479-5488. [CrossRef] [PubMed] 
11. Collins, A.R. The comet assay for DNA damage and repair: Principles, applications, and limitations. Mol. Biotechnol. 2004, 26, 249-261. [CrossRef]

12. Fikrova, P.; Stetina, R.; Hronek, M.; Hyspler, R.; Ticha, A.; Zadak, Z. Application of the comet assay method in clinical studies. Wien. Klin. Wochenschr. 2011, 123, 693-699. [CrossRef] [PubMed]

13. McKenna, D.J.; McKeown, S.R.; McKelvey-Martin, V.J. Potential use of the comet assay in the clinical management of cancer. Mutagenesis 2008, 23, 183-190. [CrossRef] [PubMed]

14. Banath, J.P.; Olive, P.L. Expression of phosphorylated histone H2AX as a surrogate of cell killing by drugs that create DNA double-strand breaks. Cancer Res. 2003, 63, 4347-4350. [PubMed]

15. Grosse, N.; van Loon, B.; Rohrer Bley, C. DNA damage response and DNA repair-dog as a model? BMC Cancer 2014, 14, 203. [CrossRef] [PubMed]

16. Khanna, C.; Lindblad-Toh, K.; Vail, D.; London, C.; Bergman, P.; Barber, L.; Breen, M.; Kitchell, B.; McNeil, E.; Modiano, J.F.; et al. The dog as a cancer model. Nat. Biotechnol. 2006, 24, 1065-1066. [CrossRef] [PubMed]

17. Park, S.H.; Kang, H.J.; Kim, H.S.; Kim, M.J.; Heo, J.I.; Kim, J.H.; Kho, Y.J.; Kim, S.C.; Kim, J.; Park, J.B.; et al. Higher DNA repair activity is related with longer replicative life span in mammalian embryonic fibroblast cells. Biogerontology 2011, 12, 565-579. [CrossRef] [PubMed]

18. Strom, T.; Hoffe, S.E.; Fulp, W.; Frakes, J.; Coppola, D.; Springett, G.M.; Malafa, M.P.; Harris, C.L.; Eschrich, S.A.; Torres-Roca, J.F.; et al. Radiosensitivity index predicts for survival with adjuvant radiation in resectable pancreatic cancer. Radiother. Oncol. 2015, 117, 159-164. [CrossRef] [PubMed]

19. McKeown, S.R.; Robson, T.; Price, M.E.; Ho, E.T.; Hirst, D.G.; McKelvey-Martin, V.J. Potential use of the alkaline comet assay as a predictor of bladder tumour response to radiation. Br. J. Cancer 2003, 89, 2264-2270. [CrossRef] [PubMed]

20. Moneef, M.A.; Sherwood, B.T.; Bowman, K.J.; Kockelbergh, R.C.; Symonds, R.P.; Steward, W.P.; Mellon, J.K.; Jones, G.D. Measurements using the alkaline comet assay predict bladder cancer cell radiosensitivity. Br. J. Cancer 2003, 89, 2271-2276. [CrossRef] [PubMed]

21. Collins, A.R.; Dobson, V.L.; Dusinska, M.; Kennedy, G.; Stetina, R. The comet assay: What can it really tell us? Mutat. Res. 1997, 375, 183-193. [CrossRef]

22. Klaude, M.; Eriksson, S.; Nygren, J.; Ahnstrom, G. The comet assay: Mechanisms and technical considerations. Mutat. Res. 1996, 363, 89-96. [CrossRef]

23. Olive, P.L. The role of DNA single- and double-strand breaks in cell killing by ionizing radiation. Radiat. Res. 1998, 150 (Suppl. S5), S42-S51. [CrossRef] [PubMed]

24. Dunne, A.L.; Price, M.E.; Mothersill, C.; McKeown, S.R.; Robson, T.; Hirst, D.G. Relationship between clonogenic radiosensitivity, radiation-induced apoptosis and DNA damage/repair in human colon cancer cells. Br. J. Cancer 2003, 89, 2277-2283. [CrossRef] [PubMed]

25. Bonner, W.M.; Redon, C.E.; Dickey, J.S.; Nakamura, A.J.; Sedelnikova, O.A.; Solier, S.; Pommier, Y. $\gamma \mathrm{H} 2 \mathrm{AX}$ and cancer. Nat. Rev. Cancer 2008, 8, 957-967. [CrossRef] [PubMed]

26. Rogakou, E.P.; Boon, C.; Redon, C.; Bonner, W.M. Megabase chromatin domains involved in DNA double-strand breaks in vivo. J. Cell Biol. 1999, 146, 905-916. [CrossRef] [PubMed]

27. Mirzayans, R.; Severin, D.; Murray, D. Relationship between DNA double-strand break rejoining and cell survival after exposure to ionizing radiation in human fibroblast strains with differing ATM/p53 status: Implications for evaluation of clinical radiosensitivity. Int. J. Radiat. Oncol. Biol. Phys. 2006, 66, 1498-1505. [CrossRef] [PubMed]

28. Derenzini, E.; Agostinelli, C.; Imbrogno, E.; Iacobucci, I.; Casadei, B.; Brighenti, E.; Righi, S.; Fuligni, F.; Di Rora, A.G.L.; Ferrari, A.; et al. Constitutive activation of the DNA damage response pathway as a novel therapeutic target in diffuse large B-cell lymphoma. Oncotarget 2015, 6, 6553-6569. [CrossRef] [PubMed]

29. Fontana, A.O.; Augsburger, M.A.; Grosse, N.; Guckenberger, M.; Lomax, A.J.; Sartori, A.A.; Pruschy, M.N. Differential DNA repair pathway choice in cancer cells after proton- and photon-irradiation. Radiother. Oncol. 2015, 116, 374-380. [CrossRef] [PubMed]

30. Maeda, J.; Froning, C.E.; Brents, C.A.; Rose, B.J.; Thamm, D.H.; Kato, T.A. Intrinsic Radiosensitivity and Cellular Characterization of 27 Canine Cancer Cell Lines. PLoS ONE 2016, 11, e0156689. [CrossRef] [PubMed]

31. Mariotti, L.G.; Pirovano, G.; Savage, K.I.; Ghita, M.; Ottolenghi, A.; Prise, K.M.; Schettino, G. Use of the $\gamma-\mathrm{H} 2 \mathrm{AX}$ assay to investigate DNA repair dynamics following multiple radiation exposures. PLoS ONE 2013, 8, e79541. [CrossRef] [PubMed] 
32. Menegakis, A.; Eicheler, W.; Yaromina, A.; Thames, H.D.; Krause, M.; Baumann, M. Residual DNA double strand breaks in perfused but not in unperfused areas determine different radiosensitivity of tumours. Radiother. Oncol. 2011, 100, 137-144. [CrossRef] [PubMed]

33. Paris, L.; Cordelli, E.; Eleuteri, P.; Grollino, M.G.; Pasquali, E.; Ranaldi, R.; Meschini, R.; Pacchierotti, F. Kinetics of $\gamma-\mathrm{H} 2 \mathrm{AX}$ induction and removal in bone marrow and testicular cells of mice after X-ray irradiation. Mutagenesis 2011, 26, 563-572. [CrossRef] [PubMed]

34. Olive, P.L.; Banath, J.P. Phosphorylation of histone H2AX as a measure of radiosensitivity. Int. J. Radiat. Oncol. Biol. Phys. 2004, 58, 331-335. [CrossRef] [PubMed]

35. Rube, C.E.; Grudzenski, S.; Kuhne, M.; Dong, X.; Rief, N.; Lobrich, M.; Rube, C. DNA double-strand break repair of blood lymphocytes and normal tissues analysed in a preclinical mouse model: Implications for radiosensitivity testing. Clin. Cancer Res. 2008, 14, 6546-6555. [CrossRef] [PubMed]

36. Sedelnikova, O.A.; Bonner, W.M. $\gamma \mathrm{H} 2 \mathrm{AX}$ in cancer cells: A potential biomarker for cancer diagnostics, prediction and recurrence. Cell Cycle 2006, 5, 2909-2913. [PubMed]

37. Novik, K.L.; Spinelli, J.J.; Macarthur, A.C.; Shumansky, K.; Sipahimalani, P.; Leach, S.; Lai, A.; Connors, J.M.; Gascoyne, R.D.; Gallagher, R.P.; et al. Genetic variation in H2AFX contributes to risk of non-Hodgkin lymphoma. Cancer Epidemiol. Biomark. Prev. 2007, 16, 1098-1106. [CrossRef] [PubMed]

38. Bodgi, L.; Foray, N. The nucleo-shuttling of the ATM protein as a basis for a novel theory of radiation response: Resolution of the linear-quadratic model. Int. J. Radiat. Biol. 2016, 92, 117-131. [CrossRef] [PubMed]

39. Scheidegger, S.; Fuchs, H.U.; Zaugg, K.; Bodis, S.; Fuchslin, R.M. Using state variables to model the response of tumour cells to radiation and heat: A novel multi-hit-repair approach. Comput. Math. Methods Med. 2013, 2013. [CrossRef] [PubMed]

40. Yu, Y.; Zhu, W.; Diao, H.; Zhou, C.; Chen, F.F.; Yang, J. A comparative study of using comet assay and $\gamma \mathrm{H} 2 \mathrm{AX}$ foci formation in the detection of $N$-methyl- $N^{\prime}$-nitro- $N$-nitrosoguanidine-induced DNA damage. Toxicol. In Vitro 2006, 20, 959-965. [CrossRef] [PubMed]

41. Begg, A.C. Predicting response to radiotherapy: Evolutions and revolutions. Int. J. Radiat. Biol. 2009, 85, 825-836. [CrossRef] [PubMed]

42. Torres-Roca, J.F.; Stevens, C.W. Predicting response to clinical radiotherapy: Past, present, and future directions. Cancer Control. 2008, 15, 151-156. [PubMed]

43. Olive, P.L.; Banath, J.P. The comet assay: A method to measure DNA damage in individual cells. Nat. Protoc. 2006, 1, 23-29. [CrossRef] [PubMed]

44. Qvarnstrom, O.F.; Simonsson, M.; Johansson, K.A.; Nyman, J.; Turesson, I. DNA double strand break quantification in skin biopsies. Radiother. Oncol. 2004, 72, 311-317. [CrossRef] [PubMed]

45. Rogakou, E.P.; Pilch, D.R.; Orr, A.H.; Ivanova, V.S.; Bonner, W.M. DNA double-stranded breaks induce histone H2AX phosphorylation on serine 139. J. Biol. Chem. 1998, 273, 5858-5868. [CrossRef] [PubMed]

46. MacNeill, A.L. Cytology of canine and feline cutaneous and subcutaneous lesions and lymph nodes. Top. Companion Anim. Med. 2011, 26, 62-76. [CrossRef] [PubMed]

47. Cancedda, S.; Marconato, L.; Meier, V.; Laganga, P.; Roos, M.; Leone, V.F.; Rossi, F.; Rohrer Bley, C. Hypofractionated radiotherapy for macroscopic canine soft tissue sarcoma: A retrospective study of 50 cases treated with a $5 \times 6$ Gy protocol with or without metronomic chemotherapy. Vet. Radiol. Ultrasound 2015, 57, 75-83. [CrossRef] [PubMed]

48. Keyerleber, M.A.; McEntee, M.C.; Farrelly, J.; Podgorsak, M. Completeness of reporting of radiation therapy planning, dose, and delivery in veterinary radiation oncology manuscripts from 2005 to 2010. Vet. Radiol. Ultrasound 2012, 53, 221-230. [CrossRef] [PubMed]

49. Rohrer Bley, C.; Blattmann, H.; Roos, M.; Sumova, A.; Kaser-Hotz, B. Assessment of a radiotherapy patient immobilization device using single plane port radiographs and a remote computed tomography scanner. Vet. Radiol. Ultrasound 2003, 44, 470-475. [CrossRef] [PubMed]

50. Iliakis, G.; Wu, W.; Wang, M. DNA double strand break repair inhibition as a cause of heat radiosensitization: Re-evaluation considering backup pathways of NHEJ. Int. J. Hyperther. 2008, 24, 17-29. [CrossRef] [PubMed]

(C) 2017 by the authors. Licensee MDPI, Basel, Switzerland. This article is an open access article distributed under the terms and conditions of the Creative Commons Attribution (CC BY) license (http:/ / creativecommons.org/licenses/by/4.0/). 